\title{
THE PEREGRINE FALCON - PAST, PRESENT AND FUTURE
}

\section{by LYNN W. OLIPHANT, ${ }^{*}$ ROBERT RAFUSE and TOM DONALD}

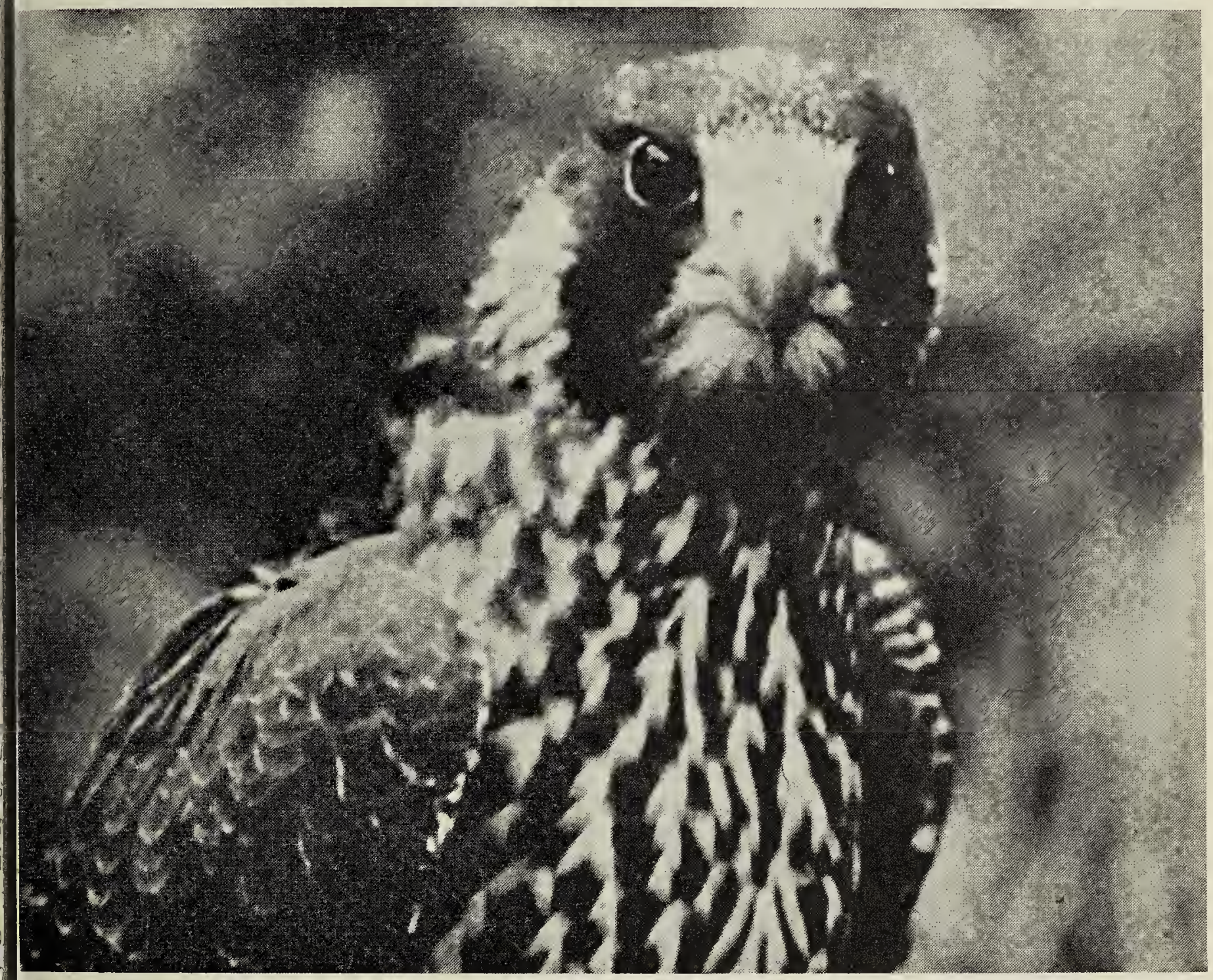

\section{THE PEREGRINE AND MAN}

In Europe, when the sport of alconry was at its height, the eregrine Falcon was perhaps the most iighly regarded and protected of all ird species. With the advent of irearms, falconry declined and with it he highly regarded status of the Peregrine subsided as well. Man no

Department of Veterinary Anatomy,

University of Saskatchewan,

Saskatoon, Saskatchewan.

S7N OWO longer cooperated with the falcon to capture game but was now a direct competitor.

In North America the Peregrine was labelled "Duck Hawk" and was persecuted because of its predatory habits. This dislike for hawks was not restricted to pigeon fanciers, game keepers and "sportsmen." Ornithologists and amateur birdwatchers also killed Peregrines because of their attacks on "good birds." Audubon, although probably not harboring the intense hatred of some, wrote of the Peregrine: 
"I can well recollect the time when, if I shot one or two individuals of the species in the course of a whole winter, I thought myself a fortunate mortal; whereas of late years I have shot two in one day, and perhaps a dozen in the course of a winter. It is quite impossible for me to account for this increase in their number, the more so that our plantations have equally increased, and we have now three gunners for every one that existed twenty years ago, and all of them ready to destroy a hawk of any kind whenever an occasion presents itself."

Attitudes changed slowly and it was only within the last 20 years that the Peregrine has received widespread legal protection.

In the late 1950's, it became evident that all was not well with some Peregrine populations. A marked decrease in usage of traditional eyries in Europe and eastern North America was noted. In 1965, at Madison, Wisconsin, an international conference on the status of the Peregrine revealed the extent of the decrease in these populations. The Peregrine was virtually extinct as a breeding species in the eastern United States and had undergone serious declines in the western United States and southern Canada."

A number of hypotheses that attempted to explain the decline were advanced at the Madison conference. The most widely accepted theory correlated the decline with the usage of certain persistent pesticides. Since the 1965 conference many studies have been conducted which substantiate this theory. Organochlorine pesticides are known to reach high levels in the tissues of predators through a cumulative effect as these chemicals pass through each level of a food chain. These persistent pesticides are believed to interfere with reproduction by causing thinning and accidental breakage of egg shells and possibly by altering behaviour of the adults. ${ }^{15}$

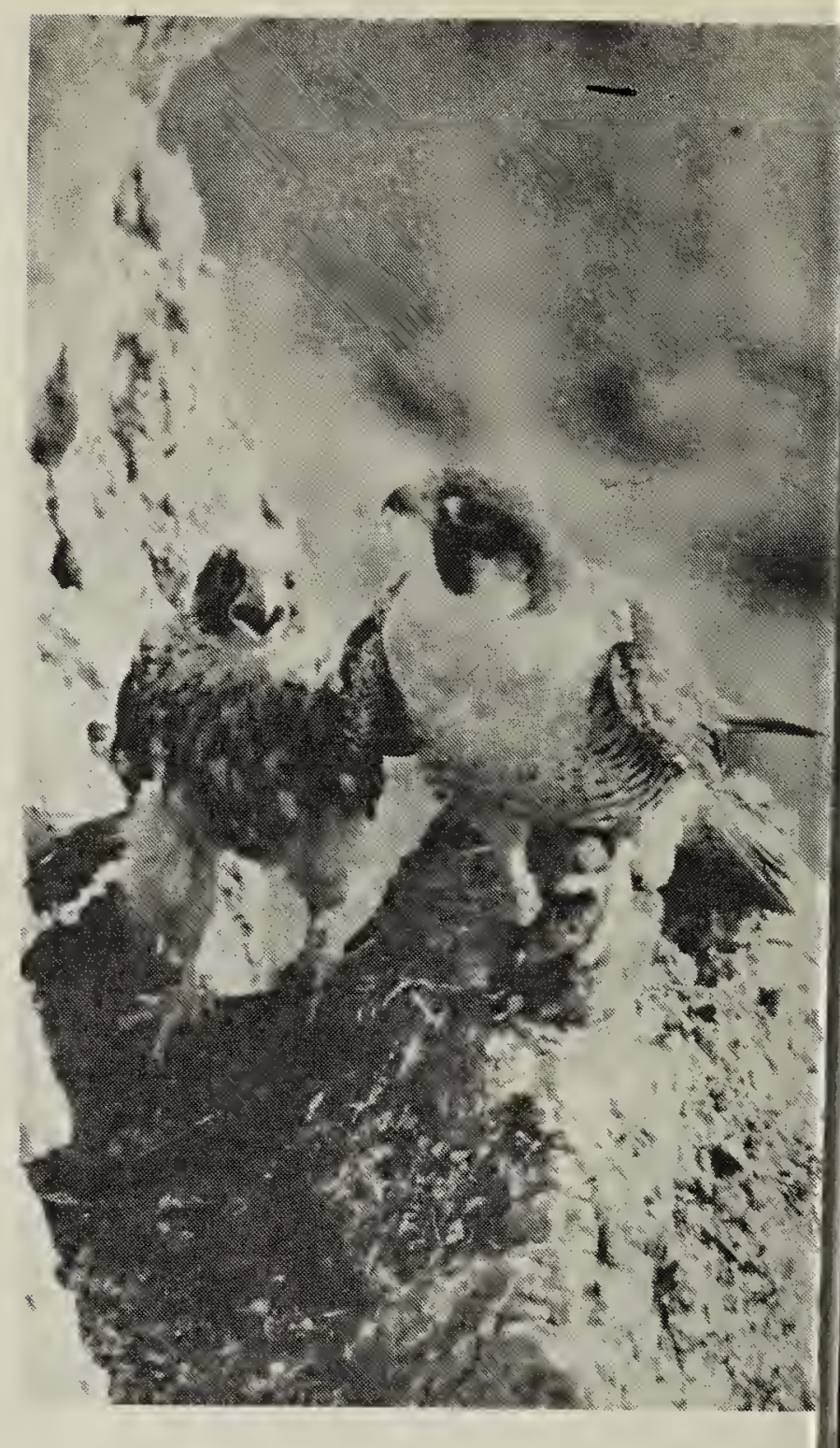

Female Peregrine with prey for 5-week-ol young, Alberta.

Richard Fyf

A tremendous amount of attentio has been focused on the extirpation the Peregrines breeding in easter North America by many conservation oriented groups which have used th Peregrine to symbolize the plight , species endangered through man abuse of the environment. Because this, there has been a tendency fo people unfamiliar with the species $t$ assume that the population in easter North America represented the maje breeding population on this continen

\section{PRESENT STATUS OF THE PEREGRINE}

The Peregrine has a world-wid distribution, occurring on all the cor tinents except Antarctica and on mo: of the major islands. It is found on greater portion of the land surface 
pair in $1968 .^{4}$ One well-studied part of this population declined to about onethird of its former numbers between the mid-1950's and the mid-1960's ${ }^{\circ}$ but has remained more or less stable sinee then (Nelson and Myres, Condor, in press).

The population on the Aleutian Island chain has been estimated at 300 pair. ${ }^{7}$ This population appears to be in good shape, experiencing rather low levels of pestieide eontamination and eggshell thinning and reproducing fairly well but containing diseoneerting levels of PCB's (an industrial pollutant). ${ }^{19}$

The Tundra Peregrine nests in Greenland and throughout the North Ameriean Arctie, north of the treeline. It represents the largest segment of the Peregrine population in North Ameriea and is the most migratory of the three subspeeies, wintering in Central and South America. ${ }^{18}$

The Anatum Peregrine formerly inhabited most of the rest of North America. During the last few deeades it disappeared as a breeding bird in the eastern United States and has been reduced to a few dozen pair in the western United States and southern Canada." In a survey of the Rocky Mountain states in 1973, the population was found to have declined by at least $50 \%$ and the 14 pair found attempting to breed fledged a total of three young. ${ }^{\rtimes}$ The Anatum still oeeurs in substantial, though redueed, numbers in the boreal forest from the interior of Alaska through the Yukon and Northwest Territories. In 1970 four previously studied areas were surveyed in this region and all showed between 40 and $65 \%$ oceupancy. ${ }^{7}$

The combined populations of Anatum and Tundra Peregrines in northern Canada (north of $55^{\circ} \mathrm{N}$ ) were estimated at over 7,500 breeding pairs in the mid-1960's." At the time of the Madison Peregrine Conference
(1965), the populations in northern Canada and Alaska appeared vigorous and unaffected by the decline which had taken place in southern Canada and in the southern 48 United States By 1970, data on seven populations from Alaska to Ungava showed deelines in the number of pairs, poor reproduetion and/or evidence of relatively high pesticide levels."

The 1970 North Ameriean Peregrine Survey, organized by Tom Cade of the Cornell Laboratory of Ornithology and Riehard Fyfe of the Canadian Wildlife Service, represented a great deal of effort by many investigators Even so, only a portion of even prime Peregrine habitat could be covered 117 eyries in northern Canada anc Alaska, along with mueh potentia nesting habitat. However, the fact that all the sample areas whieh were studied showed the faleons to be ex perieneing diffieulties strongly suggested that the norther populations too had beeome involvec in the same problems which had earlier crippled the southerr populations. More recent work or Tundra and Anatum populations in both the Canadian and Alaskan Aretic indicate the declines are eontinuing t the extent that some populations Tundra and Anatum Peregrines are of the verge of extinction. (R. Fyfe, pers eomm.)

It is difficult to assess productivity of birds sueh as the Peregrines that breed at low densities over vast areas Attempts have been made to monito their population trends at concen tration points during migration to avoid these diffieulties. Migratin Peregrines pass down the Atlanti coast, over the Great Lakes and alon the Gulf coast of Texas. Studies ir these areas have indicated no obviou decrease in numbers in recent years and, in general, the adult/immatur ratios of the migrants suggest that th northern populations have bee 


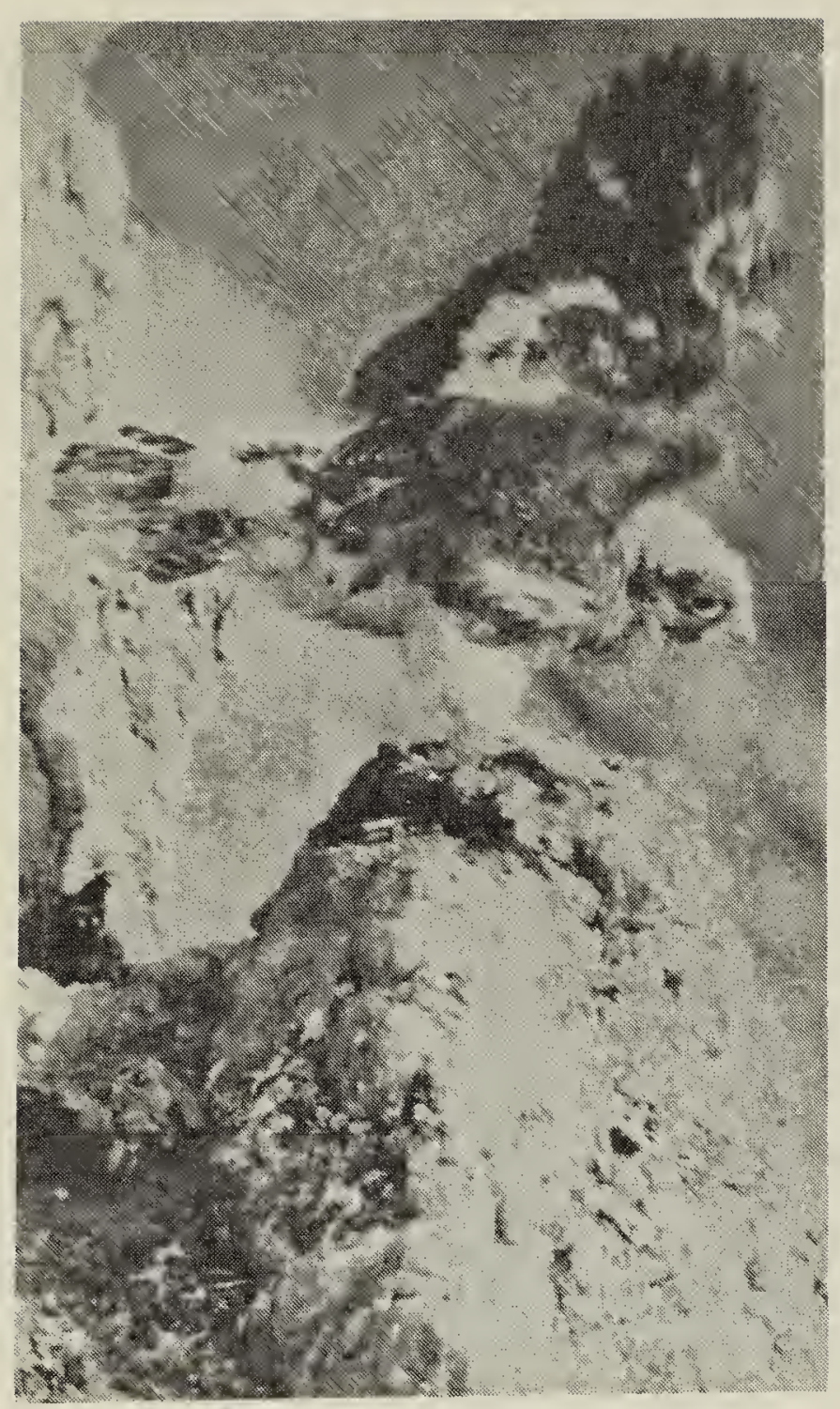

Five-week-old young flapping, Alberta.

Richard Fyfe

Cade $^{\text {; }}$ has proposed that restrieted zones be established around historie eyrie sites. This is espeeially important where remnant populations are in easily aecessible areas and will be important when reintroduetion begins in areas which have lost wild nesting Peregrines.

It is evident, however, that protection alone is a meaningless gesture. The preservation of an adequate environment is essential for the eontinued survival of the Peregrine. Ensuring a ehemieally noneontaminated environment is most important as well as being the most diffieult to implement.

Several management teehniques have been proposed as a means of inereasing wild Peregrine populations." Produetivity at the nest ean be inereased by "double elutehing." This involves the early removal of the firs set of eggs to a foster parent or in eubator for hatehing. The wild pai ean then lay and rear a sceond elute and the young from artifieially in eubated eggs ean be returned to th wild, effeetively doubling the produc tion of the wild pair. In 1974 th Canadian Wildlife Serviee did just thi at two Peregrine eyres (R. W. Fyfe personal eommunication).

Beeause natural mortality of youn Peregrines is very high, their survive rate could be inereased by holdin them in eaptivity for the first 2 year. They eould be eared for and flown $b$ master faleoners and "hacked back (gradually aequainting young with th wild until independent) to the wild the time of spring migration. The num ber surviving eould probably be least doubled by this teehnique wit the additional advantage of being ab to insure little or no contamination their food in eaptivity with pestieides Such a program would of cours require eareful coordination and ac ministration.

A major program presently und way is the eaptive breeding of th Peregrine for eventual reintroduetio Many projeets, both institutional an private, are eurrently involved in ea tive propagation. Cornell University Laboratory of Ornithology establishe a Peregrine breeding projeet in 197 In 1973 , they produced 20 young fro 3 adult pairs. In 1974, they produee 23 young from 5 pair of adults. So $f_{t}$ Cornell has achieved the greatest su eess in eaptive breeding of th Peregrine and their enthusiasm exemplified by this quote from the 1974 Newsletter:

"A new era in man's relations wi the faleons has beeome possible. an era in which faleoner avieulturists, eonservationists ar nature lovers ean join hands in eommon effort to preserve ar manage birds of prey for human $\mathrm{e}$ joyment and enlightenment." 
e Canadian Wildlife Service ablished a projeet in Alberta in 70 for the captive breeding of eral species of faleons. They have hieved considerable sueeess with the hirie Faleon and in 1974 were suesful in producing Peregrines.

Private breeding projeets have neered many of the techniques in tive breeding beeause they are able foeus their entire effort on one or pair of falcons. The first captived Peregrines in North America e produeed in Oregon by Larry ramm's Peale's Peregrines whieh liged one young in 1968 and two ing in 1969. Heinz Meng, in New rk State, raised one young Peale's in 1 and seven in 1972. In 1973, his ilt pair went to Cornell's breeding ject. John Campbell of Alberta had cess with a pair of northern atums in 1973 (3 young) and in 74 (2 young). An important elight of this particular breeding ject has been the excellent havioural information that has been hered by Wayne Nelson, University Calgary and John Campbell. ${ }^{1: 3}$ it eral other private projects have duced young Peregrines in both rada and the United States sinee 70.

The Prairie Falcon is a eommon eding falcon in parts of the west is similar in many ways to the egrine. It is, therefore, useful as an crimental species for trying various eding and release techniques that tht be perfected sueeessfully enough apply to later releases of captive duced Peregrines. In Alberta, hard Fyfe is carrying out extensive arch into methods of reintroducusing Prairie Falcons for eximental trials.

n 1974, there were some releases of tive produced Peregrines to the d. Heinz Meng released a pair of ng falcons from the Faeulty Tower of the State University at New Paltz, New York, hoping they would establish territory there. Unfortunately, shortly after they beeame independent they were killed by an unknown person. ${ }^{12}$

Cornell researehers placed two young Peregrines from their projeet into an eyrie in Colorado whieh had a long history of nesting failure. The young fledged normally and were observed some time later flying about their foster home.

\section{THE FUTURE OF THE PEREGRINE}

In some ways the future of the Peregine looks bright. The halting of the deeline in parts of Great Britain and the partial recovery of the Peregrine population there is encouraging. Legislation reducing the use of some persistent pesticides has been enaeted in many eountries including Canada and the United States. The reeent advaneement in eaptive breeding suceess and the eontinued development of other management teehniques is also heartening.

We should not, however, lose sight of the faet that even speeies with large populations ean become extinct in a very short period of time as shown by the disappearance of the Passenger Pigeon. The use of persistent pestieides is still very high in many developing countries and may be a source of contamination for our aretic migrant Peregrines. As world food production beeomes further outstripped by world population increases, there may also be increased pressure to revert to widespread use of these chemicals in North America.

Hopefully, the fact that a major effort has begun while there still are viable populations of Peregrines in North America will ensure that future generations will be able to see this magnifieent bird across the full extent of its former range. 
The authors wish to thank R. Wayne Nelson and Richard Fyfe for many helpful suggestions about this paper.

'AUDUBON, J. J. The hirds of America. 1967. Vol. 1, Dover Publ.

"BERGER, D. D., D. W. ANDERSON, J. D. WEAVER and R. W. RISEBROUGH. 1970. Shell thinning in eggs of Ungava Peregrines, Can. Field-Nat. 84: 265-267.

"BLAKEMAN, J. A. 1974. How many raptors? Hawk Chalk 13(3): 31-33.

'BLOOD, D. A. 1968. Population slatus of' Peregrine Falcons in the Queen Charlotte Islands, British Columbia. Can. Field-Nat, 82: 169-176. 176.

BROWN, L. and D. AMADON. 1968. Eagles, hawks and falcons of the world. Vol. 1, MeGrawHill. $945 \mathrm{p}$

"CADE, T. 1974. Plans for managing the survival of the Peregrine Falcon. Proe. of the Cont. on Raptor Conservation Techniques. Raptor Res. Foundation.

CADE, T. and R. W. FYFE, 1970. The Norlh America Peregrine survey. Can. Field-Nat. 84: $231-245$.

ENDERSON, J. H. and J. CRAIG. 1974. Sialus of the Peregrine Falcon in the Rocky Monntain states. Auk. 9l(4): 727-736.

"HICKEY. J. 1969. Peregrine Falcon populations. their biology and decline. Univ. Wisconsin Press. $596 \mathrm{p}$.

"HUNT, G. and R. RODGERS, 1973. Texas Peregrine Falcons. Texas Ornith. Soc., December Newsletter.

"LINCER, J. L., T. J. CADE and J DEVINE, 1970. Organochlorine residues Alaskan Peregrine Faleons (Falco peregrinus stall). Rougli-legged Hawks (Buleo lago) pus oppidau) and lleir prey. Can. Field-Nat. $255-263$.

1'MENG, H. 1974. Director's reporl. Hawk Cl 13(3): $5-7$.

13NELSON, R. W. and J. A. CAMPBELL. I Breeding and beluvior of arclic Peregrines in livily. Hawk Chalk 12(3): 39-54.

WNELSON, R. W. and J. A. CAMPBELL. 19 Breeding and helavioner of caplive ar Peregrines. Hawk Chalk 13(3): 44-61.

1.5RATCLIFFE, D. A. 1970. Changes altrihu (1) pesticides in egg breakage frequency egyshell lhickness in some British birds. J. plicd Ecology, 7: 67-115

"WARD, F. P. and R. B. BERR Y. 1972. Aw" migrations of Peregrine Falcons on Assat Island, 1970-7l. J. Wildlife Man. 36: 484

'THACKER, R. 1974. Tle' Peregrine II ference. Hawk Chalk 1.3(1): 23-30.

1*WHITE, C. 1968. Diagnosis and relationshi Norlle America landra-inhabiting Pere Falcons. Auk. 85: 179-191.

1:WHITE, C. M.. W, B. EMISON and F. WILLIAMSON. 1973. DDE in a res Aleutian Island Peregrine population. Co 75: 306-311.

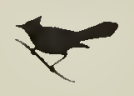

\section{CALGARY BLUEBIRD TRA
by HAROLD W. PINEL**
and CAROL J. ROBINSON*}

Because of the success of the Calgary Bluebird Trail in its initial year, 1973, we decided to double the number of nesting boxes in 1974 from 191 to 382. First, all the boxes vandalized or missing from the 1973 trail were repaired or replaced. Then in early March of 1974, nest boxes used the previous year were cleaned out and

\footnotetext{
*1017 - 19th Ave., N.W

Calgary, Alberta. T2M $0 \mathrm{Z8}$
**Group Box 3
9th Ave. and 22nd St., S.E.,
Calgary, Alberta.

sprayed with a creolin solution (1 creolin to 10 parts $\mathrm{H}_{2} \mathrm{O}$ ) to destroy and other insects. In late Marc 1974, the 191 new houses were erc in different areas as continuatior the already existing trail (Fig bringing the trail to about $220 \mathrm{~m}$

Every nesting box was checked the contents recorded four time: tween the 3 rd week in May and th week in August.

Of the 382 boxes, 42 were dalized before nesting began, 4 nesting started and 35 were 